\title{
Antioxidant activity of some coumarins Antioxidačná activita niektorých kumarínov
}

\author{
${ }^{1}$ Comenius Univerzity in Bratislava, Faculty of Natural \\ Sciences, Institute of Chemistry, Slovak republic \\ ${ }^{2}$ Comenius University in Bratislava, Faculty of Natural \\ Sciences, Department of Organic Chemistry, Slovak republic
}

${ }^{1}$ Univerzita Komenského v Bratislave, Prírodovedecká fakulta, Chemický ústav, Slovenská republika

I Univerzita Komenského v Bratislave, Prírodovedecká fakulta, Katedra organickej chémie, Slovenská republika

Received November 30, 2014, accepted January 30, 2015

Abstract Nineteen derivatives of coumarin were tested on the scavenging of 2,2-diphenyl-1-picrylhydrazyl, hydroxyl and superoxide anion radicals. It was found that antioxidant activity exhibits only such coumarins that contain hydroxyl groups. The derivatives without hydroxyl group showed very low antioxidant effectiveness or they were ineffective. On the other hand, the greatest antioxidant effectiveness was exhibited by coumarin derivatives that contained hydroxyl groups in 6 or 8 position, whereas the effectiveness of derivatives with one hydroxyl group in 4, 5 or 7 position was very low. Based on scavenging of the above-mentioned radicals, it was found that the most effective scavengers were 7,8-dihydroxy-4-methylcoumarin (i.e. compound that contains two hydroxyl groups in 7 and 8 positions), (7,8-dihydroxy-2-oxo-2H-chromen-4-yl)acetic acid (this compound contains in addition to two hydroxyl groups in 7 and 8 positions also one hydroxyl group in the acidic residue), esculetin (6,7-dihydroxycoumarin) and 6,7-dihydroxy-4-methylcoumarin.

Slovak Otestovali sme devätnást' derivátov kumarínu, na vychytávanie DPPH, hydroxylových, a superoxidových aniónových radikálov. abstract Ich antioxidačná účinnost' bola závislá od počtu a lokalizácie hydroxylových skupín. Deriváty, ktoré nemali žiadnu hydroxylovú skupinu boli vel'mi slabo účinné, alebo vôbec neúčinné. Najúčinnejšie vychytávače radikálov boli tie deriváty kumarínu, ktoré obsahovali hydoxylové skupiny v polohe 6 alebo 8. Na druhej strane deriváty, ktoré mali iba jednu hydroxylovú skupinu v polohe 4, 5 alebo 7 boli vel'mi slabo účinné. Najúčinnejšie vychytávače vyššie spomínaných radikálov boli 7,8-dihydroxy-4-metylkumarín (zlúčenina, ktorá obsahuje 2 hydroxylové skupiny na benzénovom jadre v polohe 7 a 8), 7,8-dihydroxykumarín-4-yl-octová kyselina (obsahuje okrem 2 hydroxylových skupín na benzénovom jadre má aj OH skupinu v kyselinovom zvyšku, eskuletín (6,7-dihydroxykumarín) a 6,7-dihydroxy-4-metylkumarín.

Keywords coumarins-DPPH-EPR-hydroxyl-superoxide anion radicals - scavenger activity

Klúčové kumaríny - DPPH - EPR - hydroxyl - superoxid anión radikály-skavengerová aktivita

slová:

\section{INTRODUCTION}

Coumarins are compounds with extensive biologic activities. They can be found to occur naturally in a lot of plants (green beans, lavender, licorice/liquorice, apricots, strawberries, cherries, aloe), also in bacteria and fungi. Coumarins were long ago used as spices and aromatic additives in traditional medicine. Some natural polyphenolic coumarins show anti-inflammatory, antimicrobial, antivirus, anticancer, anticoagulant (as rodenticides) and antioxidant activity (Bentley 1972; Borges et al., 2005; Kostova et al., 2011; Leung et al., 2005; Pedersen et al., 2007; Valchev et al., 2008). Coumarins act also as pesticides in the plants that produce them (Hoult \& Payá, 1996; Murray et al., 1982). It was found that esculetin retards senescence and decreases lipid peroxidation (Martin-Arago et al., 1998) protects human hepatoma HepG2 cells from hydrogen peroxide-induced oxidative damage (Subramaniam \& Ellis 2011). Chemical terms of coumarin are 1 - benzopyran-2-one or $2 \mathrm{H}$-chromen2-one. Some coumarins that can be found to occur naturally are umberlliferone (7-hydroxycoumarin is used in sunscreen), esculetin (6,7-dihydroxycoumarin), warfarin and imperatorine (acting as anticogulants), herniarine (acts as antiallergic or fungicide), psoralen (used for psoriasis treatment).

The goal of this work is to determine the antioxidant activity (by scavenging 2,2-diphenyl-1-picrylhydrazyl (DPPH), hydroxyl and superoxide anion radicals) of some natural and synthetic coumarins and to investigate the relation between their antioxidant efficiency and structure.

*E-mail:sersen@fns.uniba.sk

๑) Acta Facultatis Pharmaceuticae Universitatis Comenianae 


\section{MATERIALS AND METHODS}

\section{Reagents and equipments}

DPPH, 5,5-dimethyl-1-pyroline- $N$-oxide (DMPO), esculetin, 2-mercaptoethanol, $\beta$-nicotinamide adenine dinucleotid sodium salt (NADH) were delivered by Sigma-Aldrich Ltd. Methanol p.a., EDTA, $\mathrm{MnCl}_{2^{\prime}} \mathrm{FeSO}_{4}$ and $30 \% \mathrm{H}_{2} \mathrm{O}_{2}$ were from the Centralchem firm (Slovakia). Further coumarin derivatives were prepared according to the work of Furdik et al., 1957. Absorption spectra were recorded using spectrophotometer Genesis 6 (Thermo-Scientific, USA). Electron paramagnetic resonance (EPR) spectra were recorded by EPR spectrometer ERS 230 (ZWG Berlin, Germany), which works in X region (approximately $9.3 \mathrm{GHz}$ ), with amplitude modulation $0.1 \mathrm{mT}$, at microwave power $5 \mathrm{~mW}$.

\section{DPPH assay}

Scavenging of DPPH radicals by studied coumarins was monitored by the method, which was described in our previous work Šeršeň et al., 2005. Various amounts of tested compound were added into methanol solution of DPPH and the resulting DPPH concentration was kept constant $\left(\mathrm{c}=10^{-4}\right.$ mol dm${ }^{-3}$ ). Twenty minutes after the addition of the tested substance, absorbance was measured at $517 \mathrm{~nm}$.

\section{Hydroxyl radical assay}

Scavenging of hydroxyl radicals was monitored by the method described in our previous works (Valentová et al., 2005, Šeršeň et al., 2005). Hydroxyl radicals were generated by Fenton reaction using $\mathrm{H}_{2} \mathrm{O}_{2}$ and $\mathrm{FeSO}_{4}$. Because $\mathrm{HO}$ radicals are very unstable, it is impossible to determine them directly by continual wave EPR spectrometer. Therefore, $\mathrm{HO}$ radicals captured by the spin trap DMPO and EPR spectra of spin adduct DMPO $+\mathrm{OH}$ were recorded. Reaction solution was phosphate buffer $\left(0.19 \mathrm{mmol} \mathrm{dm}^{-3} \mathrm{Na}_{2} \mathrm{HPO}_{4^{\prime}} \mathrm{pH}=7.4\right.$.), which contained $5.10^{-4} \mathrm{~mol} \mathrm{dm}^{-3} \mathrm{FeSO}_{4^{\prime}} 0.025 \mathrm{~mol} \mathrm{dm}^{-3} \mathrm{DMPO}, 0.05$ mol dm${ }^{-3} \mathrm{H}_{2} \mathrm{O}_{2}$ and $0-1 \mathrm{mg} \mathrm{cm}^{-3}$ of the tested substance. EPR spectra of these solutions prepared in this way were recorded 20 minutes after the addition of $\mathrm{H}_{2} \mathrm{O}_{2}$.

\section{Superoxide anion radical assay}

Scavenging of superoxide anion radicals $\left(\mathrm{O}_{2}^{-}\right)$was monitored according to the work of Valentová et al., 2005. $\mathrm{O}_{2}^{--}$radical was generated from $\mathrm{O}_{2}$ in the presence of EDTA, $\mathrm{MnCl}_{2^{\prime}} \mathrm{NADH}$ and 2-mercaptoethanol. The reaction mixture contained $0.8 \mathrm{~cm}^{3}$ of phosphate buffer $\left(19 \mathrm{mmol} \mathrm{dm}^{-3} \mathrm{Na}_{2} \mathrm{HPO}_{4^{\prime}} \mathrm{pH}=7.4\right)$, and the tested sample $\left(0.1 \mathrm{~cm}^{-3}\right.$ with concentration 0.0001 $1 \mathrm{mmol} \mathrm{dm}^{-3}$ ) was incubated for 20 minutes. The reaction was started with the addition of 2-mercaptoethanol $\left(0.1 \mathrm{~cm}^{3}\right.$, $10 \mathrm{mmol} \mathrm{dm}^{-3}$ ). Twenty minutes after the addition of 2-mercaptoethanol a decrease of absorbance at $340 \mathrm{~nm}$ was recorded.
From the concentration dependencies were calculated $\mathrm{SC}_{50}$ values, i.e. concentrations of the studied compound that decrease the absorbance or the intensity of the EPR signal to the value of $50 \%$ with respect to the control. All measurements were carried out at laboratory temperature.

\section{RESULTS}

Scavenging of DPPH radicals by studied compounds is illustrated in Table 1. From this table, it is evident that coumarin derivatives without hydroxyl groups in benzene ring have very low activity (compounds No. 6, 10, 12 - 15) or they are ineffective (compounds No. 10, 16 -19). On the other hand, coumarins that contain one $\mathrm{OH}$ group exhibit very low antioxidant activity (compounds No. $5,7,11$ ) or they are ineffective (compound No. 8). Coumarins with 2 hydroxyl groups in positions 7,8 (compounds No. 1 and 2) or 6,7 (compounds No. 3 and 4) exhibit very good antioxidant efficiency, whereas compound (No. 9) with 2 hydroxyl groups in positions 5,7 has very low activity.

Scavenging of $\mathrm{HO}$ radicals was documented by EPR spectroscopy. Fig. 1 shows typical spectra of DMPO adduct

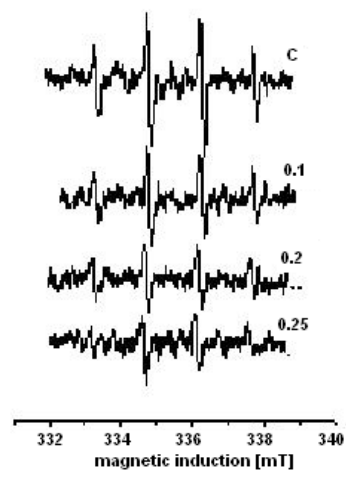

A

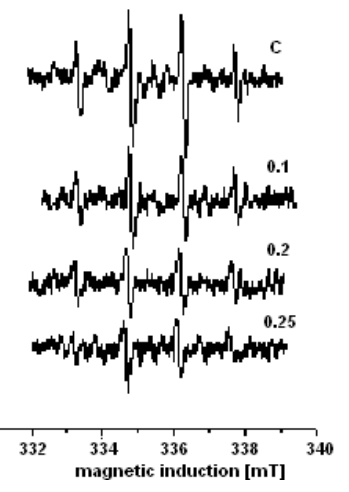

B

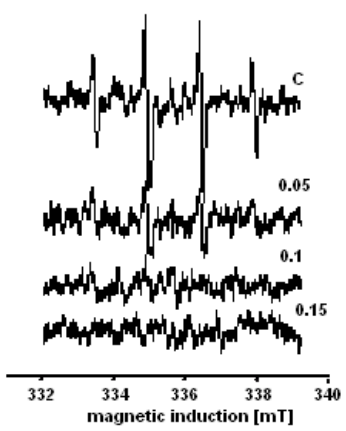

C

Figure 1. EPR Spectra of spin adduct of DMPO with hydroxyl radicals at the presence of different amount (in mg) 7,8-dihydroxy-4-methylcoumarin (A), 6,7-dihydroxycoumarin (B) and (7,8-dihydroxy-2-oxo$2 \mathrm{H}$-chromen-4-yl)acetic acid (C). 
Table 1. SC $\mathrm{C}_{50}$ values of coumarins determined by scavenging DPPH radicals

\begin{tabular}{|c|c|c|c|c|}
\hline No. & Compound & $\mathrm{SC}_{50} \mu \mathrm{mol} \mathrm{dm}{ }^{-3}$ & $r^{2}$ & Name \\
\hline 1 & & 6.31 & 0.999 & (7,8-dihydroxy-2-oxo-2H-chromen-4-yl)acetic acid \\
\hline 2 & & 8.43 & 0.973 & 7,8-dihydroxy-4-methylcoumarin \\
\hline 3 & & 8.64 & 0.987 & $\begin{array}{l}\text { 6,7-dihydroxycoumarin } \\
\text { (esculetin) }\end{array}$ \\
\hline 4 & & 10.36 & 0.987 & $\begin{array}{l}\text { 6,7-dihydroxy-4-methylcoumarin } \\
\text { (4-methylesculetin) }\end{array}$ \\
\hline 5 & & 4125 & 0.616 & $\begin{array}{l}\text { 7-hydroxycoumarin } \\
\text { (umberlliferone) }\end{array}$ \\
\hline 6 & & 5448 & 0.996 & $\begin{array}{l}\text { 2H-chromen-2-one } \\
\text { (coumarin) }\end{array}$ \\
\hline 7 & & 796 & 0.997 & 4-hydroxycoumarin \\
\hline 8 & & ineffective & & 7-hydroxy-4-methylcoumarin \\
\hline 9 & & 870 & 0.773 & 5,7-dihydroxy-2-oxo-2H-chromen-4-carboxylic acid \\
\hline 10 & & ineffective & & 2-oxo-2H-chromen-3-carboxylic acid \\
\hline 11 & & 247/0.917 & & 5-hydroxy-7-methoxy-2-oxo-2H-chromen-4-carboxylic acid \\
\hline 12 & & 4021 & 0.621 & 5,7-dimethoxy-2-oxo-2H-chromen-4-carboxylic acid \\
\hline 13 & & 1106 & 0.958 & $\begin{array}{l}\text { 6,8-dibromo-3-((2,6-dimethylphenyl)thio)-2H-chromen-2- } \\
\text { one }\end{array}$ \\
\hline 14 & & 1349 & 0.912 & 2-(3-oxo-3H-benzo[f]chromen-1-yl) acetic acid \\
\hline 15 & & 2073 & 0.922 & 2-((2-oxo-2H-chromen-3-yl)oxy)benzoic acid \\
\hline 16 & & ineffective & & $\mathrm{N}$-(2-oxo-2H-chromen-3-yl)benzamide \\
\hline 17 & & ineffective & & 2-(2-(2-oxo-2H-chromen-3-yl)acetyl)benzamide \\
\hline 18 & & ineffective & & 6-bromo-3-((4-nitrophenyl)thio)-2H-chromen-2-one \\
\hline 19 & & ineffective & & $\begin{array}{l}\text { 7-methyl-4-((2-oxo-2H-chromen-3-yl)thio)-2H-chromen- } \\
\text { 2-one }\end{array}$ \\
\hline
\end{tabular}




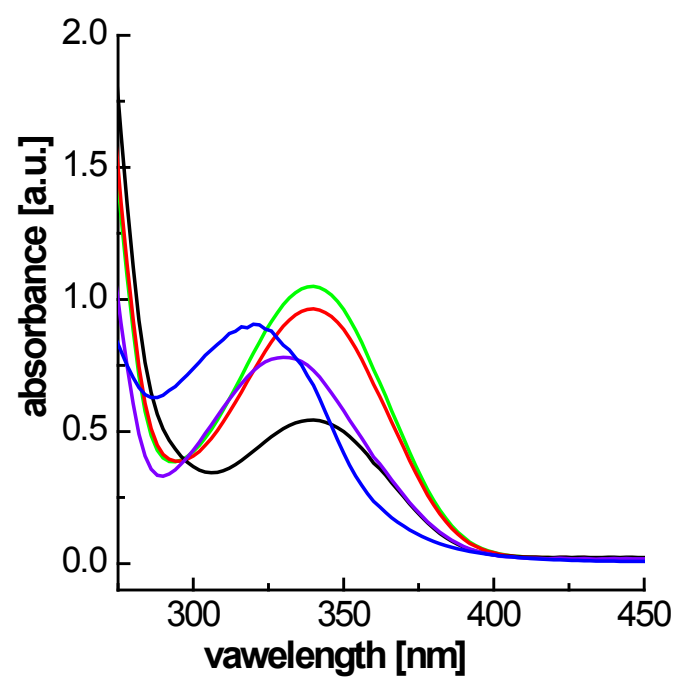

Figure 2. Absorption spectra of $\mathrm{NADH}$ (green line), in the presence of $\mathrm{O}_{2}^{--}$radicals without coumarins (black line), and in the presence of $2.810^{-5} \mathrm{~mol} \mathrm{dm}^{-3}$ esculetin (red line), 7,8-dihydroxy-4-methylcoumarin (blue line) and (7,8-dihydroxy-2-oxo-2H-chromen-4-yl)acetic acid (violet line).

with $\mathrm{HO}$ radical. Effect of the antioxidant is documented as decrease of intensity of EPR signal. $\mathrm{SC}_{50}$ values were calculated as concentration causing the $50 \%$ decrease of intensity of the second line in the EPR spectrum.

Scavenging of $\mathrm{O}_{2}^{--}$radicals was documented by absorption spectra of $\mathrm{NADH}$ solutions. The intensity decrease of absorption band at $340 \mathrm{~nm}$ is caused by the oxidation of $\mathrm{NADH}$ by the superoxide anion radical. This decrease is lower in the presence of antioxidants, which is documented in Fig. 2. $\mathrm{SC}_{50}$ values were calculated as concentration causing the decrease absorbance at $340 \mathrm{~nm}$ to $50 \%$ against to control sample.

Antioxidant efficiency of the most active coumarins expressed as the ability of scavenging DPPH, hydroxyl and $\mathrm{O}_{2}^{--}$radicals is presented in Table 2.

\section{DISCUSSION}

We tested 19 coumarin derivatives on antioxidant activity. It was found that their antioxidant efficiency was determined by the number and the position of hydroxyl group in their benzene ring. From Table 1, it is evident that the best scavengers of DPPH radicals are coumarins that have hydroxyl group in the position 6 or 8 in their structure. Their efficiency decreased in following order: 7,8-dihydroxycoumarin4-yl-acetic acid > 7,8-dihydroxy-4-methylcoumarin > 6,7-dihydroxycoumarin > 6,7-dihydroxy-4-methylcoumarin. The other coumarins that had hydroxyl group in the position 4 (compound No. 7), 5 (compound No. 11) or 7 (compound
Table 2. Scavenging of DPPH, $\mathrm{HO}$ and $\mathrm{O}_{2}^{--}$radicals expressed through $\mathrm{SC}_{50}$ values of coumarins $\left(\mu \mathrm{mol} . \mathrm{dm}^{-3}\right)$.

\begin{tabular}{|c|c|c|c|c|}
\hline No. & Compound & $\mathrm{DPPH} / \mathrm{r}^{2}$ & $\mathrm{HO} / \mathrm{r}^{2}$ & $\mathrm{O}_{2}^{--} / \mathrm{r}^{2}$ \\
\hline 1 & $6.31 / 0.9989$ & $7.43 / 0.939$ & $19.21 / 0.830$ \\
\hline 2 & $8.43 / 0.93$ & $9.18 / 0.913$ & \\
\hline
\end{tabular}

$r^{2}$ - the average square deviation

No. 8) showed very low antioxidant efficiency. On the other hand, the efficiency of derivatives without hydroxyl groups was also very low or such derivatives were ineffective.

Some of the studied coumarins (No. 2 - 8) have been previously tested for antioxidant activity; the remaining 12 substances (No. 1, 9 - 19) are tested for the first time. Comparing the DPPH scavenging activity of some coumarins in this study (7,8-dihydroxy-4-methylcoumarin, esculetin, 4-methylesculetin, umberlliferone, coumarin, 4-hydoxycoumarin and hymecromone) with results of other authors (Hoult \& Payá 1996, Panteleon et al., 2003, and Rehakova et al., 2008), it was found that our results are in good agreement with those of the authors mentioned above. Somewhere there were any differences among $\mathrm{SC}_{50}$ values obtained by us and those obtained by those authors, these could be caused by different measurement methods. However, the tendency between their structure and antioxidant activity are identical. Morabito et al., 2010 found that 4-methyl coumarins that had the $\mathrm{OH}$ groups, in positions 7 and 8, substituted acetoxy groups showed lower antioxidant activity than those with $\mathrm{OH}$ groups. This finding is in accordance with our results since coumarins without hydroxyl groups were ineffective or they exhibited very low antioxidant activity. Our results are also in agreement with the works of Pedersen et al., 2007, Barzegar et al., 2011 and Razo-Hernandez et al., 2014 who found that the most active scavengers of DPPH and galvinoxyl radicals were 6,7- and 7,8-dihydroxy-4-methyl coumarins. Also, Kaneko et al., 2001 found that esculetin bearing a 6,7-dihydroxyl moiety showed a protective effect on linoleic acid hydroperoxide-induced toxicity, whereas 4- and 7- hydroxycomarins were ineffective. From the structure-activity studies by Payá et al., 1993 and Morabito et al., 2010, the importance of an ortho-dihydroxyl function, especially at the position 7 and 8 can be deduced. Based on the results of tests concerning DPPH scavenging, the most efficient derivatives of coumarin were chosen and these were tested on scavenging of hydroxyl and superoxide 
anion radicals. Tested compounds were 7,8-dihydroxy-4methylcoumarin (a compound that contains 2 hydroxyl groups on the benzene ring in the 7 and 8 positions), 7,8-dihydroxycoumarin-4-yl-acetic acid (compound that contains besides two hydroxyl groups on the benzene ring also an $\mathrm{OH}$ group in the acid rest) and 6,7-dihydroxycoumarin and their antioxidant efficiency is presented in Table 2. From this table, it is evident that these coumarins are also very good scavengers also hydroxyl and $\mathrm{O}_{2}^{-}$-radicals. Our findings are in accordance with those of Panteleon et al., 2003 and Lin et al., 2008 , who found scavenging of hydroxyl radicals by esculetin and 4-methyl esculetin. It was confirmed that coumarins with $\mathrm{OH}$ groups in positions 7 and 8 were very good scavengers of $\mathrm{O}_{2}^{--}$radicals (see Table 2). A similar effect was also observed by Hoult \& Payá 1996, and Morabito et al., 2010, that is, the most effective coumarins were dihydroxy coumarins, in particular those that contained $\mathrm{OH}$ groups in positions 7 and 8.

\section{CONCLUSION}

It was found that from the aspect of antioxidant activity of coumarins, the most important factor is the number and the position of hydroxyl groups on the coumarin skeleton. The most effective coumarins contained two hydroxyl groups on the benzene ring, especially in positions 7 and 8. Coumarins with one or without hydroxyl groups showed very low antioxidant activity or were inactive. Also, it was found that the most effective scavengers of DPPH radicals were also very good scavengers of hydroxyl and superoxide anion radicals.

\section{ACKNOWLEDGEMENT}

This work was financially supported by the VEGA grant agency of the Ministry of Education of Slovak Republic no. 1/0612/11

\section{References}

[1] Barzegar A, Davari MD, Chaparzadeh N, at al. Theoretical and Experimental Studies on the Structure-Antioxidant Activity Relationship of Synthetic 4-Methylcoumarins. J Iran Chem Soc. 2011;8:973-982.

[2] Bentley EW. A review of anticoagulant rodenticides in current use. Bull W H O. 1972;47:275-280.

[3] Borges F, Roleira F, Milhazes N, Santana L, Uriarte E. Simple coumarins and analogous in medicinal chemistry: occurrence, synthesis and biological activity. Curr Med Chem. 2005;12: 887916.

[4] Furdík M, Hrnčiar P, Lácová M. Contribution to prepare 4-comarine acetic acid. Acta Facul. Rerum Nat Univ Comen. 1957;1:471-481. (in Slovak)

[5] Hoult JRS, Payá M. Pharmcological and biochemical actions of simple coumarins: Natural products with therapeutic potential. Gen Pharmacol. 1996;27:713-722.

[6] Kaneko T, Baba N, Matsuo M. Structure-activity relationship of antioxidants for inhibitors of linoleic acid hydroperoxideinduced toxicity in cultured human umbilical vein endothelial cells. Cytotechnology 2001; 35:43-55.

[7] Kostova I, Bhatia S, Grigorov P, et al. Coumarins as antioxidants. Curr Med Chem. 2011;18:3929-3951.

[8] Leung KN, Leung PY, Kong LP, Leung PK. Immunomodulatory effects of esculetin (6,7-dihydroxycoumarin) on murine lymphocytes and peritoneal macrophages. Cell Mol Immunol. 2005;2:181-188.

[9] Lin HC, Tsai SH, Chen CS, et al. Structure-activity relationship of coumarin derivatives on xanthine oxidase-inhibiting and free radical-scavenging activities. Biochem Pharmacol. 2008;75:14161425.

[10] Martin-Arago S, Benedi JM, Villar AM. Effects of the Antioxidant (6,7-Dihydroxycoumarin) Esculetin on the Glutathione System and Lipid Peroxidation in Mice. Gerontology. 1998;44:21-25.

[11] Morabito G, Trombetta D, Singh B.K, et al. Antioxidant properties of 4-methylcoumarins in in vitro cell-free systems. Biochimie. 2010;92:1101-1107.
[12] Murray RDH, Mendez J, Brawn SA. The Natural Coumarins, Willey, New York 1982.

[13] Panteleon V, Marakos P, Pouli N, Mikros E, Andreadou I. Interactions of a series of novel spiropyranocoumarin derivatives with reactive oxygen species. J Pharm Pharmacol. 2003;55:10291039.

[14] Payá M, Ferrándiz ML, Miralles F, Montesinos C, Ubeda A, Alcazar MJ. Effects of coumarin derivatives on superoxide anion generation. Arzneim-Forsch. 1993;43:655-658.

[15] Pedersen JZ, Oliveira C, Incerpi S, et al. Antioxidant activity of 4-methylcoumarins. J Pharm Pharmacol. 2007;59:1721-1728.

[16] Razo-Hernandez RS, Pineda-Urbina K, Velazco-Medel MA, et al. QSAR study of the DPPH center dot radical scavenging activity of coumarin derivatives and xanthine oxidase inhibition by molecular docking. Cent Eur J Chem. 2014;12:1067-1080.

[17] Rehakova Z, Koleckar V, Cervenka F. et al. DPPH Radical Scavenging Activity of Several Naturally Occurring Coumarins and Their Synthesized Analogs Measured by the SIA Method. Toxicol Mech Method. 2008;18:413-418.

[18] Šeršeň F, Mučaji $P$, Grančai $D$, Nagy M. Antioxidantive properties of methanol extracts from leaves and fruits of Ligustrum vulgare L. Acta Facult Pharm Univ Comen. 2005;52:204-210.

[19] Subramaniam SR, Ellis EM. Esculetin-induced protection of human hepatoma HepG2 cells against hydrogen peroxide is associated with the Nrf2-dependent induction of the NAD(P)H: Quinone oxidoreductase 1 gene. Toxicol Appl Pharm. 2011;250:130-136.

[20] Valchev I, Binev R, Yordanova V, Nikolov Y. Anticoagulant Rodenticide Intoxication in Animals - A Review. Turk J Vet Anim Sci. 2008;32:237-243.

[21] Valentová K, Šeršeň F, Ulrichová J. Radical scavenging and anti-lipoperoxidative activities of Smallanthus sonchifolius leaf extracts. J Agric Food Chem. 2005;53:5577-5582. 